\title{
Electrical Neuromodulation and the Heart with Special Emphasis on Myocardial Ischemia
}

\author{
Mike J.L. DeJongste \\ Department of Cardiology, Thoraxcenter, University Medical Center \\ Groningen and University of Groningen, Groningen \\ The Netherlands
}

\section{Introduction}

To describe the relation between the nervous system and the heart Natelson, among others, coined the term 'neurocardiology' in the eighties of the previous century. ${ }^{1}$ In the nineties, the scope of neurocardiology was broadened by researchers from a largely neuroanatomical point of view to a focus that was more directed onto interaction between heart and nervous system from an integrative physiology focus. Finally, the center of attention of neurocardiology also shifted onto experimental science and technology at the neural interface of the heart. More specifically, the clinical interest became directed towards basic science through studying (modulation of) recruited neuro-humoral, neuro-inflammatory and neural pathways, in the presence or absence of angina pectoris, resulting from myocardial ischemia. ${ }^{2}$

In this respect, the chapter briefly highlights the available conventional therapies for ischemic heart diseases, followed by a discussion on efficacy and underlying neurocardiological mechanisms of available electrical neuromodulation therapies. In addition, a systematic and detailed review is offered on the antiischemic effects of electrical neuromodulation in patients with end-stage coronary artery disease.

\section{Ischemic cardiovascular diseases}

The average life span of the Western population has doubled over the last century as a consequence of major progress made in developments in socio-economic policies and improvements in hygiene. Further, advancements have been accomplished in preventive procedures and in the improvement of an armamentarium of therapeutic strategies to treat (infectious) diseases. Subsequently, to date in the Western world, civilians are no longer subjected to the deleterious menaces of infectious diseases and life expectancy is largely determined by atherosclerotic diseases and cancer, each presently representing $1 / 3$ of all deaths.

With respect to cardiovascular diseases, as a consequence of preventive measures such as life style changes (among others: stopping smoking, increasing physical exercise, eating healthy food, reducing stress and treating risk factors), pharmacotherapeutics (nitroglycerin, beta-blockers, calcium-antagonists, renin-angiotensin-aldosteron system blockers, lipid 
lowering drugs, anticoagulants) and revascularization procedures (percutaneous coronary interventions [PCI] and coronary artery bypass surgery [CABS]), mortality from cardiovascular diseases has declined significantly during the last four decades. As a consequence, more patients will survive their heart disease for a longer period. Moreover, since the population is graying and therapies have been improved, it is to be expected that the number of patients suffering from ischemic heart disease will increase. Ischemic heart disease is most often the consequence of atherosclerotic narrowing of one or more coronary arteries. During exercise, when the heart muscle demands more oxygen, the shortage in oxygen supply, due to the narrowed coronary arteries, provokes chest discomfort, so-called angina pectoris.

\subsection{Angina pectoris}

Stable angina is considered as a clinical syndrome, characterized by indistinctly distributed chest distress, described as sensations of tightness, pressure, heaviness, squeezing, burning, or choking provoked during exercise. The occurrence of angina and its emotional components have been brilliantly expressed by Heberden in $1772 .{ }^{3}$ In acute cardiovascular syndromes a coronary artery is closed up and chest discomforts occur at rest, while angina is not relieved by nitroglycerin use. Specifically in acute syndromes these symptoms are often escorted with vaso-vegetative and emotional sensations such as nausea, transpiration, anxiety or thoughts of an impending death.

To examine the neural pathways, involved in ischemia-induced angina, the heart-brain axis is the subject of many years' thoughtful research on the nervous involvement in cardiac control. Following the development of a model for angina, we and others have injected analgesic substances, such as bradykinin and capsaicin, ${ }^{4}$ to study the involved nervous pathways, by means of the early gene c-fos. ${ }^{5}$ Exploration of this neurocardiological field of interest has also been focus of behavioral aspects of angina ${ }^{6}$ and made the participation of the transient receptor potential vanilloid-1 (TRPV-1), at the heart likely.7 Virus tracing studies executed by means of a pseudo-rabies virus, injected into the myocardium, made it possible to visualize the stained recruited pathways. 8,9 See for an overview of our studies on neurocardiology reference ${ }^{10}$.

\subsection{Chronic refractory angina}

In spite of many innovative developments in pharmacotherapeutic and surgical treatment strategies, which have significantly improved life expectancy of patients suffering from ischemic heart disease, an increasing number of patients are resistant to all conventional opportunities. These patients remain severely disabled and suffer from chest discomfort during minimal exercise, or sometimes even at rest. They typically have become refractory to maximal tolerated standard anti-ischemic medication and are no longer candidates for revascularization procedures, such as PCI and CABS.11 The presence of myocardial ischemia should be clinically established to be the cause of symptoms. ${ }^{12}$ Patients enduring this condition are usually characterized by a long history of artery disease, have received at least one revascularization(s) procedure(s), are between sixty and seventy years of age, of the male gender, experienced one or more myocardial infarction, however, have maintained the left ventricular ejection fraction. ${ }^{13}$ Furthermore, due to progress of their coronary disease, these patients most often experience life threatening events such as an acute coronary 
syndrome and therefore the need of hospital admission.14 The patients have become an increasing medical and psychosocial problem resulting from their devastating chest discomforts. The impact of the severe complaints of angina on social life and quality of life of these patients is often underestimated. ${ }^{15}$ Whether this is a syndrome that differs from the chronic angina patients is doubtful.

Life expectancy of these patients varies in the literature between 5-8\% which may be considered as fairly favorable. In this regard, these patients may be considered as survivors of their coronary artery disease. It is estimated that the incidence is about $1: 10,000$ the prevalence is 1:30,000 and the total number in the Western World is over 200,000.16 Since more patients survive their disease, perceived quality of life issues become more important for these patients. Because the patients are severely hindered by their severe angina and because conventional treatment options are lacking, the patients have unmet medical needs. As a consequence, therapies relieving their angina, without adversely influencing their prognosis are imperative. From this point of view, exploration of newer therapies has to be promoted with the emphasis on a reduction of both ischemic burden and angina, so that the patients may subsequently harvest an improved quality of life. During the last decade for patients with surgically and pharmacologically uncontrollable chronic angina, several additional therapies have become available, ${ }^{17}$ of which electrical neuromodulation may be considered to be one of the safest, most effective and best evaluated strategies in the current therapeutic arsenal, currently available for these patients.18,19 In this regard, electrical neuromodulation has become accepted as an adjunct therapy for refractory angina pectoris in the ACC/ AHA guidelines since 2002.20

\section{Myocardial ischemia (see Fig 1)}

To enhance the metabolism of the muscles during exercise, sufficient oxygen is required. The heart receives oxygenated blood from the lungs and exchanges the oxygen for $\mathrm{CO}_{2}$ at the muscular level, more specifically via the mitochondrial membrane of the muscle cell. However, the heart muscle itself also needs oxygen to perform its contracting force. The heart muscle receives its oxygen through the coronary arteries. At rest, the heart subtracts about $95 \%$ of the oxygen from the coronary arteries. The only option the heart muscle has to subtract more oxygen from the coronary arteries is to dilate its coronary artery vascular tree. Subsequently, the cardiac oxygen supply can increase five fold to meet the increased oxygen demand. In a normal situation, exercise is limited through a shift from aerobic to anaerobic metabolism. As a result of this metabolic change more effluents (lactate, potassium etc) are produced. These effluents activate chemical and mechanical receptors in the heart (among others TRPV1), conveying signals to the brain which result in withholding exercise, most often because of fatigue and dyspnea (vide infra). However, in the presence of coronary artery disease, the atherosclerotic plaque reduces the dilatory facilities of the coronary artery and so the aerobic threshold is reached much sooner. The (exercise) induced discrepancy between oxygen supply and demand is called myocardial ischemia. Stable angina comprises that the complaints of angina are induced during exercise. The heart muscle (myocardium) becomes 'ischemic' at the aerobic threshold at which the critical balance between oxygen $\left(\mathrm{O}_{2}\right)$ supply and demand is perturbed (Figure 1). The metabolic demand of the heart is determined mainly by contraction force -build upon the amount of ATP energy storage- and the product of heart rate and systolic blood pressure, the so-called rate pressure product (RPP) or double product. The increase in $\mathrm{O}_{2}$ demand, as is required during cardiac stress, is proportional to the increase in the RPP. ${ }^{21}$ 


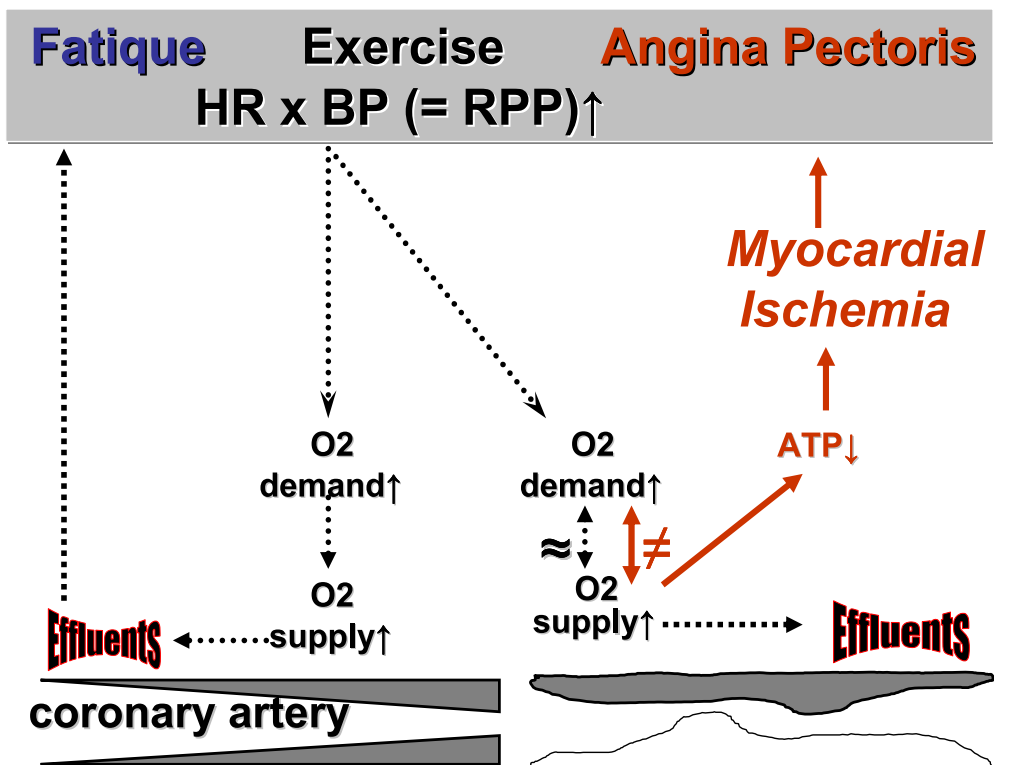

$\neq=$ mismatch. $\mathrm{HR}=$ heart rate. $\mathrm{RPP}=$ rate pressure product; $\mathrm{BP}=$ blood pressure; $\mathrm{ATP}=$ adenosine triphosphate.

Fig. 1. See text for details

\subsection{Ischemic heart disease}

The most common manifestation of ischemic coronary artery disease (CAD), the leading cause of death in the United States, is angina pectoris. In a substantial proportion $(\sim 10.2$ million) of the estimated 17.6 million affected American patients with obstructive CAD, angina has become the main clinical symptom.

Many strategies have been developed to improve the ischemic capacity through reducing the demand (by means of, for instance, $\beta$-blocking agents) or by improving the supply (by means of, for example, revascularization). Novel approaches are required to improve clinical outcomes in patients with coronary heart disease. To date the focus of antiischemic therapies is also on making the heart, i.e. the myocyte, more resistant to ischemic challenges by enhancing the ischemic threshold, which is determined by both collateral flow and preconditioning. These two alternatives improve the ischemic tolerance and will be discussed further.

\subsection{Cardiac microcirculation}

A pluriform array of mechanisms, including metabolic, neural and myogenic systems are involved in regulating blood flow within the coronary vascular tree; increases in blood flow involve corresponding increases in vessel diameter at the level of the small vessels and arterioles. In the heart, diminished oxygen delivery in response to myocardial ischemia is countered by an increase in regional blood flow and functional capillary density within the microcirculation. Under resting conditions only a small number of coronary capillary vessels 
in the heart are open for blood flow; during exercise (increased oxygen demand) additional capillary vessels are opened (i.e., recruited). Understanding the various factors that control post-ischemic coronary capillary blood flow across the myocardial wall remains an important challenge. In the setting of coronary artery disease, maldistribution of blood flow is attributed to dysfunction of specific components of the vessel wall, in particular the endothelium.

Of fundamental importance for post-ischemic tissue viability in the heart is the delivery of oxygen and nutrients, either via pre-existing coronary vascular or collateral networks or via promotion of new vessel growth (i.e., vasculogenesis or neovascularization). In a canine preparation of chronic myocardial ischemia, Kersten and co-workers documented that coronary collateral development in response to repeated coronary occlusions requires an extended timeframe for coronary collateral growth. ${ }^{22}$ These findings confirmed earlier results that coronary collateral conductance improved over time and was associated with increased transmural distribution of blood flow in the heart after brief coronary occlusion in the canine.

Remodeling of existing small vessels by addition of vascular smooth muscle cells and extracellular matrix around a larger diameter may be important in formation of collateral vessels. There is ample reference to coronary collateral recruitment at onset of ischemia in the scientific literature. It would be more reasonable to use the terminology of microvessel or capillary recruitment (as suggested initially by Krogh in his capillary-tissue exchange cylinder model). He reported that opening of coronary collateral channels occurs in man during coronary occlusion. ${ }^{23 a, b, c}$ More recently ischemic adaptation to collateral channel opening was observed during ischemic preconditioning, which is thought to play an important role in the development of ischemic tolerance. ${ }^{24}$ In animal experiments "opening" of coronary collateral channels has not been documented;25 this would suggest that augmented blood flow to ischemic myocardium in animals via capillary vessels does not play a role in the cardioprotective actions induced by preconditioning. Consequently, experimental studies may not provide sufficient evidence to elucidate the underlying mechanisms of action of electrical neuromodulation in humans.

\subsection{Ischemic preconditioning (IPC) and postconditioning}

In their recent report on ischemic conditioning, described as "the practice of applying brief episodes of nonlethal ischemia and reperfusion to confer protection against a sustained episode of lethal ischemia and reperfusion injury", the authors discuss this potentially therapeutic strategy. ${ }^{28}$ They noted that the protective stimulus can be applied before ischemic preconditioning (IPC), during the onset of sustained episodes of lethal ischemia (ischemic conditioning), or at the onset of myocardial reperfusion (ischemic postconditioning)." In brief, IPC is an intrinsic process, usually induced by repeated short periods of ischemia, most often performed through a temporary occlusion of a vessel, through pharmacological substances, or through exercise stress to protect the myocardium against a subsequent ischemic insult. The phenomenon was described first by Murry et al, in 1986, exposing anesthetised dogs to 5 minutes of coronary artery occlusions, followed by a 5 minute period of reperfusion and finally to a 40 minute continuous occlusion. In controls ischemic preconditioning was withheld. The control animals experienced larger infarct sizes, compared to the preconditioned dogs. ${ }^{26}$ IPC was initially thought to be the result of slower ATP-energy depletion, later interference with effectors of cell death, free radicals, attenuation of mitochondrial permeability and involvement of adenosine, opioid receptors 
and connexin 43.27 Ischemic postconditioning, a series of mechanical interruptions of reperfusion after ischemia, is performed immediately after reperfusion, for protection of myocardium against infarction, secondary to ischemia and reperfusion damage. ${ }^{28}$ Albeit that basic evidence of conditioning is abundant, its clinical effect remains debatable since mechanism of action remain partly unraveled, making translation to patients still difficult.

\section{Methods of electrical neuromodulation for refractory angina}

\subsection{A brief history of electrical neuromodulation methods}

The encouraging effects of electrical current for all kind of ailments have been in use since the pharaohs, Greeks and later the Romans. In ancient history physicians were aware of the power of electrical current, provided for instance by the electric eel, to heal discomforts, like headache and gout. ${ }^{29}$ In the early nineteenth century stimulation of nerves to reduce pain was termed electro-analgesia or electro-narcosis. ${ }^{30}$ In 1965 the landmark study by Melzack and Wall was published. They proposed the model of the gate control, ${ }^{31}$ implying that electrical current applied to the myelinated, relatively fast conducting, thicker A-fibers, modulates the pain processing in the non-myelinated slower conducting C-fibers via interneurons in the dorsal horn, and so affects pain. Although the theory still stands, it is not tenable in all its aspects anymore. In higher brain centers, it was shown with positron emission tomography (PET) that angina affects areas involved in cardiovascular control. ${ }^{32}$ In patients with angina, active neuromodulation was unable to suppress the conduction of cardiac pain signals to the cerebrum, during cardiac distress. ${ }^{33}$ Comparison of these two studies demonstrated activation of the same cardiovascular control centers during active neuromodulation as were recruited following angina. At the cardiac level the intra-cardiac neurons (ICN) are considered as the final common pathway, integrating the peripheral nervous system with the heart. These ICN are hidden in the fatty patches on the heart, controlling cardiac function. The more central superimposed neural hierarchy, controlling the ICN, has been described in relation to the presence of myocardial ischemia, in detail. ${ }^{34}$

The presence of this neural environment does not make an involved placebo unlikely in the field of electrical neuromodulation. In this regard, in the 1930s, Beecher coined and described nicely the placebo effect of, among others, surgical procedures in relation to intrinsic and extrinsic factors. ${ }^{35}$ Specifically for therapies like electrical neuromodulation, with a not entirely unraveled mechanism of action, it is important to note that the therapy is conspicious for placebo. To exclude placebo as the one and only factor explaining the effect of electrical neuromodulation, unraveling of mechanisms and performing well designed studies, such as randomized control studies, are of paramount importance. Though all therapies encounter a certain percentage of placebo, since the effects of electrical neuromodulation often last for years (vide infra) and since randomized control studies (RCT) also demonstrate beneficial outcomes, it is unlikely that a placebo is the only explanation for the favorable effects of electrical neuromodulation. Further, several studies have shown clear evidence of somatic cardiovascular responses resulting from spinal cord stimulation, such as, among others, alterations in activity of spinothalamic tract cells ${ }^{36}$ and of intra cardiac neurons ${ }^{37}$ and changes in blood pressure. ${ }^{38}$

Over the last 50 years a number of techniques to produce electro-analgesia have been reported. We will briefly review these methods. 


\subsection{Stellate ganglion stimulation}

Dr Braunwald, a brilliant pioneer in cardiology and his late wife, a thoracic surgeon, modified a pacemaker device to stimulate the stellate ganglion. Already in 1967 they reported an antiangina effect using this method of electrical neuromodulation. ${ }^{39}$ In addition, they coincidently observed in a patient experiencing an acute coronary event, normalization of the ST-T segment, following active stimulation. However, in spite of the initial encouraging results, this method of neuromodulation was discarded in the beginning of the seventies, because coronary artery bypass grafting became widely available. ${ }^{40}$ In some centers, blocking of the stellate ganglion, by means of anesthetics, is still in vogue in specific circumstances. ${ }^{41}$

\subsection{Transcutaneous Electrical Nerve Stimulation (TENS)}

Since not all patients turned out to be suitable candidates for revascularization, a decade later clinicians started to use newer forms of electrical neuromodulation, such as TENS, to deal with the chest discomfort of patients. Neurostimulation for angina pectoris is usually performed by either Transcutaneous Electrical Nervous Stimulation (TENS) or by an implantable Spinal Cord Stimulator (SCS). Since 1982 TENS is considered as an effective method in the treatment of chronically disabled patients through reducing frequency and severity of the angina attacks and subsequently the necessity for the intake of short acting nitrates. ${ }^{42}$ In addition, to the improvement in quality of life, TENS also improved exercise capacity, and lactate production (vide infra). ${ }^{43}$ However, the drawback of TENS is that the plasters on the chest may induce ortho-ergic reactions (contact dermatitis) in $20-30 \%$ of the patients, come off during sweating and are difficult to attach on hairy chests or females with large mamma. ${ }^{44,45}$ So, these shortcomings often necessitate a withdrawn from TENS therapy.

\subsection{Spinal Cord Stimulation}

The story of electro-analgesia goes on with the introduction of dorsal column stimulation in 1967,46 which later was renamed epidural spinal cord stimulation (ESES) and today is known as spinal cord stimulation (SCS). However, taking into account the surgical procedure, with respect to TENS, SCS seems to be more effective with more pronounced and sustained effects, long-term. ${ }^{7}$ In 1987, in the first report on the antianginal effect of SCS in patients with refractory angina, a reduction in both the frequency and severity of angina attacks was found, in conjunction with a reduction in sublingual intake of nitrogen tablets. 48 Later many authors advocated SCS as an effective strategy for patients with severe refractory angina. In addition, in patients with a high surgical risk, SCS is even considered as a substitute for coronary artery bypass surgery. 65

The implantation procedure of this reversible non-destructive therapy is comparable to the implantation of a pacemaker, though the electrodes are placed epidurally and not in the heart. The success of SCS depends, among others, on the correct positioning of the stimulating electrode(s) in the dorsal epidural space. It is still considered mandatory that the paresthesias induced by the stimulator correspond with the area where most of the patients experience their angina. When the tip of the electrode of the SCS device is properly placed at C7-T2, the lead is anchored and connected to the implanted pulse generator (IPG). The IPG is positioned into a subcutaneously created pocket, in the chest, comparable with the placement of a pacemaker, or in the lower upper abdominal wall. The patient can (in)activate the IPG through a patient programmer or by application of a magnet. 
The question was recently posed whether paresthesias are necessary for the beneficial effects of SCS. In this respect two studies have addressed this paradigm by randomizing patients to subthreshold stimulation and stimulation with induced paresthesias. The results were contradictory. In one study the investigators argued no difference between paresthesia induced stimulation and subthreshold, however the authors observed a significant difference with very low stimulation..$^{49}$ In another recent study this observation could not be demonstrated in naive patients. 50

\subsection{Subcutaneous Electrical Nerve Stimulation (SENS)}

Subcutaneously electrical neurostimulation (SENS), also called among others SubQ, subcutaneous target stimulation, peripheral nerve or peripheral field stimulation is a promising method. ${ }^{51}$ Recently, we and others have reported on the use of subcutaneous placed leads, implicating positioning of electrodes just underneath the thoracic skin, together with a subcutaneously implanted device. This method seems to be effective in the treatment of patients with therapeutically refractory angina. ${ }^{52,53}$ Patients with severe coronary artery disease, in which withholding anti-thrombotic pharmacotherapeutics is not feasible, may be excellent candidates for both subcutaneously implanted device and leads. Other drawbacks of the SCS treatment are that electrode placement into the epidural space is rather critical when compared to epidural placement. Furthermore, a physician with neuromodulation skills is needed for placement of the electrodes under fluoroscopy, though sometimes even then an unsuitable anatomy of the spinal area makes positioning of the electrodes impossible. So, theoretically SENS may be unifying the "best of two worlds", including the better convenience in use (and efficacy?) of SCS over TENS and an implantation procedure which is more simple (cardiologists can do it themselves), possibly safer (considering the procedure) and, maybe at less cost (shorter operation procedure and lower thresholds), when compared to SCS.

\section{Electrical neuromodulation and angina}

To optimize and to tailor adjunct treatments for patients suffering from chronic refractory angina, a 'care pathway' for 'patient-centered guiding' has been developed. ${ }^{54}$ The experts propose to start with less invasive methods, such as rehabilitation and TENS, later followed by more invasive but reversible methods, such as SCS or SENS. Ultimately, destructive methods such as ablation of nerves may be carried out.

Since the first publications, abundant articles have testified that electrical neuromodulation gained credentials in efficacy as an adjuvant therapy for in patients with severe refractory angina, irrespective of whether the method is applied at the skin of the chest, ${ }^{42,43}$ cervically ${ }^{55}$ at the T1-4 thoracic level, 56,57 or subcutaneously. 52,55 To assess the efficacy of electrical neuromodulation among patients with refractory angina receiving the various forms of electrical neuromodulation, comparative randomized control studies are warranted. The studies ought to have a placebo controlled design. ${ }^{35}$ However, unfortunately the studies can not be blinded since the physician notifies the stimulation artifacts on the ECG and the patients are aware whether or not stimulation is present. These comparative studies have not yet been executed. However, there is scarce literature in open retrospective studies that SCS may be more effective than TENS. 58 The results show that SCS is effective in $80 \%$ of the patients after a period of 4 years. After that same period, TENS is effective in about $60 \%$ of the patients. On the other hand to improve the outcome, it is important to develop the 
screening before application of neuromodulation is started, since about $20 \%$ of the patients do not show improvement in quality of life following SCS implantation.

Many observational (long-term) studies on electrical neuromodulation have consistently observed a reduction in angina complaints and use of short acting nitrates 59,61,62, with a subsequent improvement in exercise capacity 59,60,61,62 and quality of life. ${ }^{15,63,64}$ Quality of life measure, in this severely disabled group of patients, is usually executed by way of questionnaires (Nottingham health profile; Short Form-20 and RAND-36) and diaries (to score the daily number of angina attacks and number of NTG intake). These findings have been substantiated by observational studies and RCTs showing that the improvements may last for up to 10 years. $60,61,63,64,65$ These measures are, however, not taken co-morbidity and personality, which factors may affect outcome parameters, into account.66,67

The major flaw of many of the clinical studies on electrical neuromodulation is the inborn weakness of all open observational designs, implicating one does not know how much bias is found in outcome parameters. On the other hand observation studies are very useful in presenting the 'real world', instead of reporting a limited number of highly selected patients, as is the case in randomized studies. ${ }^{68}$ Unfortunately, the greater part of studies regarding the subject of electro-neuromodulation for angina, are carried out with a limited number of patients. In this regard, two recent meta-analysis on randomized controlled trials (RCT) have been executed, showing significant improvements in both quality of life (Fig 2) and exercise duration (Fig 3). 69,70

\section{Health-related Quality of Life}

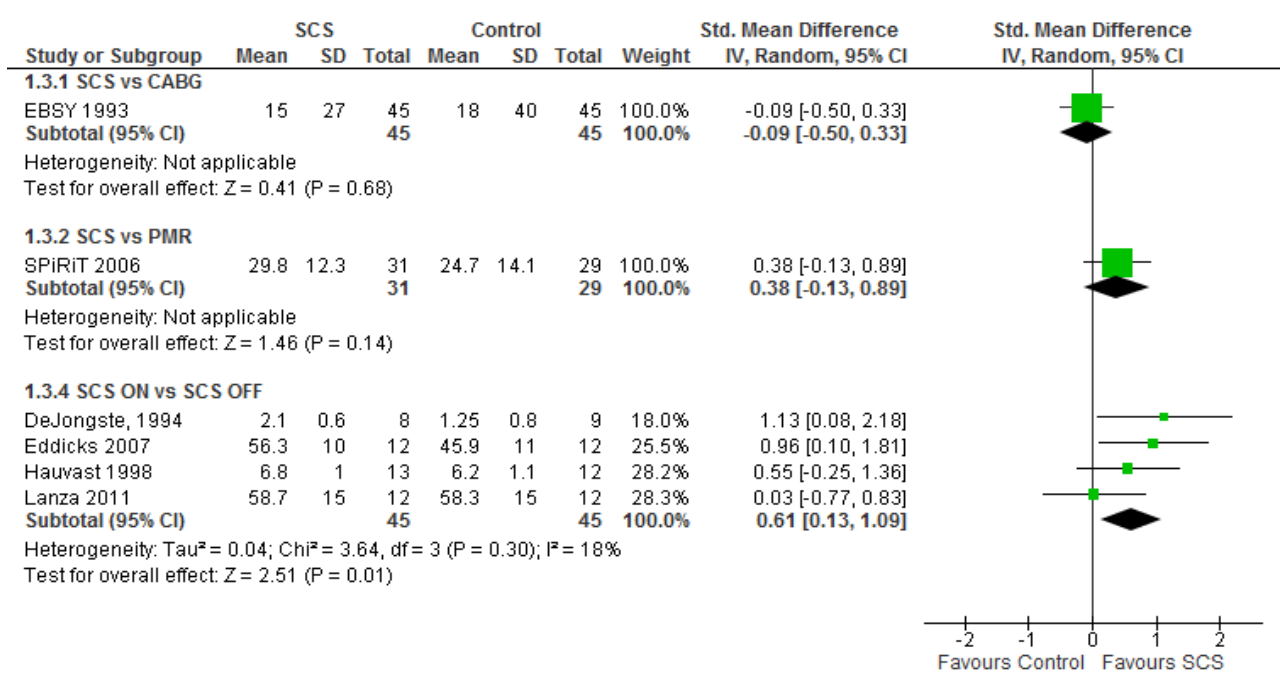

Fig. 2. Health related quality of life of 6 RCTs (adapted by R Taylor from ref. 70)

In accord with its efficacy and safety, SCS has been included in 2002 into to the ACC/AHA guidelines as an additional therapy for the treatment of this group of patients, with a class 2 indication. ${ }^{71}$ 
All modalities of electrical neuromodulation are reversible. Mainly for medico-legal reasons, combination with other devices is not advocated. ${ }^{72}$ Divergent literature is available too, reporting on the safety in combination with artificial cardiac pacemakers ${ }^{73}$ and implantable cardioverter defibrillators when specific measures are taken into account. ${ }^{74}$

With regard to the safety aspects of electrical neuromodulation, many worry as it might deprive the patients of their angina. In studies on patients with stable angina, all patients ultimately experienced angina. ${ }^{59}$ The fear for a potentially jeopardizing situation during an acute coronary syndrome, resulting from a suppressed conduction to the brain during active neuromodulation, does not seem to be justified, since electrical neuromodulation does not seem to block nociceptive information from the heart to the brain. ${ }^{33}$

Accordingly electrical neuromodulation is not found to conceal complaints of angina during a myocardial infarction since the nociceptive information on ischemia from the heart to the brain is modulated but not abolished. $75,76,77$ Electrical neuromodulation, rather than eliminating angina normalized the, through sensitization enhanced, angina threshold. The patients therefore experience an increase in exercise capacity and a reduction in severity of symptoms of angina, which does not adversely affect mortality nor morbidity. Regarding mortality in the population of patients treated with SCS for refractory angina pectoris, several studies report a relatively low annual mortality rate of about 5-7\%.13,78,79 We recently evaluated morbidity in this group of patients, by comparing medical history at baseline with follow-up data. ${ }^{66}$ Our interest in morbidity was generated by the lack of improvement in quality of life indices in a substantial number of patients, after long-term implantation of

\section{Exercise Capacity}

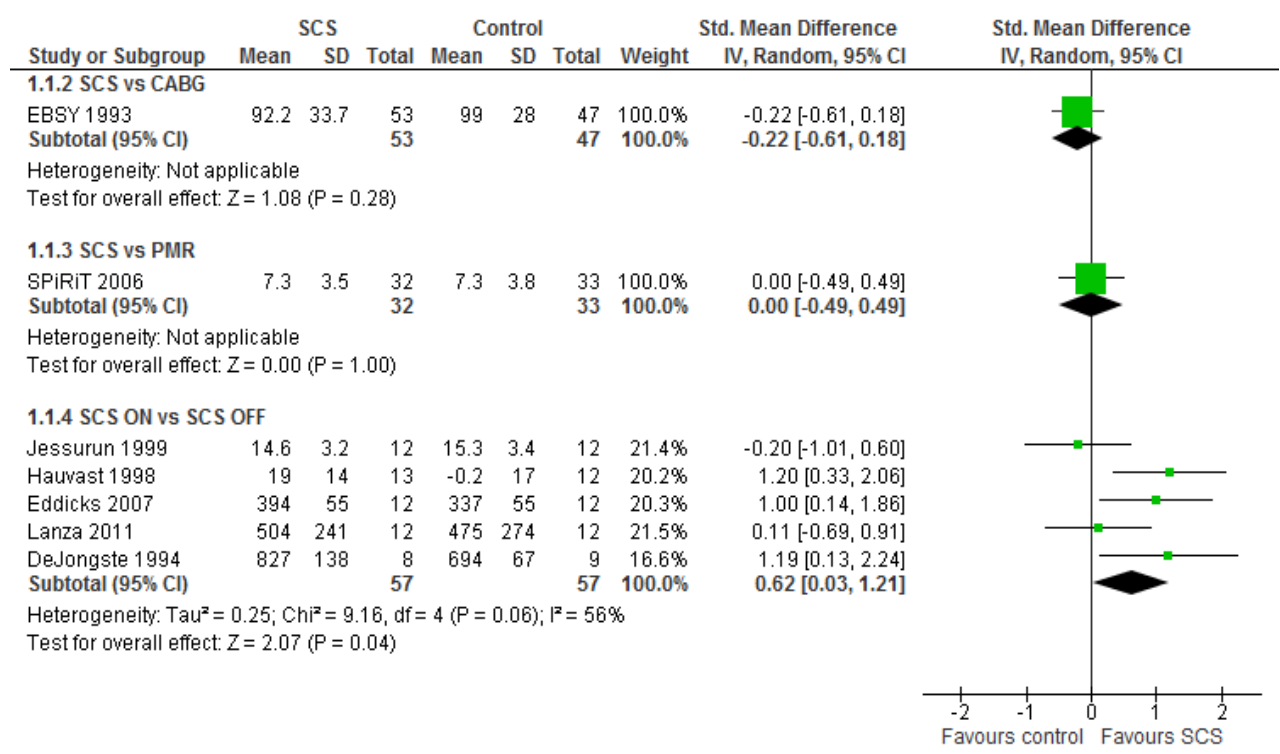

Fig. 3. Exercise tests of 7 randomized control studies (adapted by R Taylor from ref. 70) 
spinal cord stimulator. We reported that in some patients the lack of improvement in quality of life was related to the presence of co-morbidities, such as respiratory diseases, musculoskeletal disorders, diabetes and obesity. As a consequence of our analysis of the effects of SCS on quality of life, we recommend that in studies on electrical neuromodulation, the effect of co-morbidities on the quality of life is taken into account.

Several cost-benefit and cost-effectiveness studies have been performed to evaluate the costs of SCS in the treatment of refractory angina. The break-even point for costs is calculated to be about three to four years. ${ }^{80,81}$

Given the data, electrical neuromodulation is considered as one of the best and safest adjuvant therapies to consider for patients suffocating from chronic refractory angina. 82,83

In conclusion, studies with different designs have consistently demonstrated that electrical neuromodulation reduces complaints of angina, enabling patients to prolong their exercise, independent of the method applied. Whether or not electrical neuromodulation may improve myocardial ischemia is the subject of the next part of this chapter.

\section{Electrical neuromodulation and myocardial ischemia}

In the wake of many favorable outcomes on quality of life end points assessed in studies with patients suffering from chronic refractory angina pectoris, treated with electrical neuromostimulation, the debate continues whether the raise in angina threshold is associated with an improvement in ischemic tolerance.

In 1967 Braunwald et al, stimulating the stellate ganglion to achieve a reduction in complaints of angina, were the first to observe a concomitant reduction in myocardial ischemia during active stimulation. ${ }^{39,40}$ The beneficial effects of electrical neuromodulation (TENS) on the resolution of ST-segment depression in patients suffering from and following an acute coronary syndrome were later confirmed by de Vries et al. ${ }^{84,85}$ However, in spite of the antianginal and antiischemic effect, electrical neuromodulation was used in a rather limited number of patients. The restricted number of patients treated was attributed to the introduction of bypass surgery, at that time, making neuromodulation outdated. ${ }^{40}$ In addition to the reduction in angina, induced through electrical neuromodulation exerted by means of stellate ganglion stimulation, its suggested antiischemic effect was later confirmed by making use of different methods, a variety of study designs, and end points. Using TENS, in the short-term limb of the study, a reduction was reported in lactated production and ST-T segment depression during pacing-induced and a long-term improvement in exercise capacity in conjunction with a persistent ST-T segment depression during maximal exercise stress tests. ${ }^{43}$ Unfortunately, in this respect not all studies on exercise capacity are assessing ST-T segment changes, 86,87 since the recording requires either, specific filtering of the ECG signal or, temporarily withholding active stimulation during the exercise. This specific skill is related to interference of the neurostimulation induced artifacts on the ECG. Later, several observational and randomized studies, making use of this expertise to evaluate antiischemic effects of SCS, by means of bicycle or treadmill exercise stress tests as the method of choice, show consistent findings of a reduction in ST-T segment depression at maximal and at comparable work load, in conjunction with improvement in exercise duration. $57,59,61,62,63$ So, in spite of a prolonged exercise duration the patients had less myocardial ischemia. However, in a meta-analysis of 5 randomized studies on exercise stress tests ST-T segment changes were not significantly altered, following SCS (Fig 4) 
and maximal work load, and ambulatory ECG recordings, to significantly improve ST-T segment depression, considered as a marker for myocardial ischemia, these findings raise the question which neurocardiological mechanisms are involved. Therefore, electrical neuromodulation was used to examine the neural hierarchy in cardiac control.2,34

Initially, the favorable effects of SCS, for other indications than angina, were attributed to a sympathicolytic effect. 75

In 1950 Lindgren was the first to report on beneficial outcomes of bilateral upper cutting of the thoracic sympathetic nerves in patients suffering from severe angina. ${ }^{95}$ Later modulation of nerves became more accepted than the destruction of nerves. Meglio et al demonstrated a reduction in heart rate in 25 patients without overt cardiac disease with a spinal cord stimulator, implanted for pain. ${ }^{96}$ However, their early experimental finding has never been substantiated by others.

In current pharmacotherapeutical treatment of angina, B-blocking agents have become a cornerstone for 45 years. ${ }^{97}$ B-Blocker agents employ their beneficial result through their effect on the sympathetic nervous system and the subsequent decrease in rate pressure product (RPP). This reduction in RPP results in a decline in myocardial oxygen demand.

Initially, the antiischemic effect of SCS was also subscribed to modulation of the autonomic nervous system, more specifically to the sympathetic limb.

Ambulatory ECG recording have not shown a change in Heart Rate Variability (HRV), a measure of autonomic function, following electrical neuromodulation. 89,98 In the setting of patients with angina, the lack of influence of SCS on HRV may be caused by the blunting effect of $\beta$-blockers on HRV in the majority of patients with angina.

Furthermore, there is scarce evidence that SCS is still active after sympathectomy (Dr Juhl G, Danmark, personal communication), no change in cardiac epinephrine spill-over was found 94,99 and SCS does not seem to affect adrenergic function as assessed by single photon emission computed tomography either (11)C-hydroxyephedrine or iodine 123- meta-iodobenzylguanidine in patients with coronary artery disease, 100 or in patients suffering from chest pain during exercise induced ST-T segment changes but, without significant coronary artery disease (i.e. cardiac syndrome X). ${ }^{101}$

So, in the treatment of angina with SCS, clinical data do not support the hypothesis that electrical neuromodulation employs a $\beta$-sympaticolytic effect. The lack of sufficient evidence of a $\beta$-adrenergic effect of electrical neuromodulation does, of course, not exclude an asympathetic effect to be involved in changes in myocardial perfusion (vide infra). ${ }^{102}$ There is basic evidence that SCS enhances the vagal tonus. ${ }^{103}$ In concert with this observation, a study in patients with severe coronary artery disease demonstrates that vagal stimulation, inhibiting norepinephrine release from sympathetic nerves to the heart, may subsequently alter the sympatholytic/ vagotonic balance and so dilates cardiac microcirculatory vessels. ${ }^{104}$

Mannheimer and coworkers put forward the hypothesis that electrical neuromodulation reduces the myocardial oxygen demand. ${ }^{94}$ Based on the observed reduction of ST-T segment changes at comparable work load (i.e. same RPP) the researchers hypothesized that the decrease in myocardial oxygen demand subsequently reduces symptoms associated with angina pectoris. ${ }^{59}$ This hypothesis suggests involvement of a sympathicolytic effect. In 
addition, in their rapid atrial pacing study, the investigators showed an improvement in ischemic threshold during pacing induced ischemia in the presence of active SCS. In a letter to the editor of the British Medical Journal preconditioning as alternative explanation was proposed. 105 The authors based their theory on the short term between the experiment with and without SCS. In addition to ischemic preconditioning the heart is also protected during reperfusion by ischemic postconditioning, which protects the heart after the manifestation of the ischemic event through signal transduction pathways. In concert with the 'cardiac conditioning hypothesis', more plausible concepts than the reduction in myocardial oxygen demand following SCS have been postulated. These concepts are based on alterations in myocardial blood flow and subsequently in affecting myocardial perfusion.

To measure the effects in myocardial perfusion induced through electrical neuromodulation, studies have been performed with both, radionuclides and Doppler flow wires. In a study with $740 \mathrm{MBq}$ 99-Technetium-MIBI an improved flow was reported in 16 out of 27 patients, only after 1 year. 106 In 10 patients no change was showed in myocardial blood flow and in one patient myocardial blood flow worsened after one year. Since, after 3 months, the investigators reported significant improvements in symptoms of angina, but not in myocardial perfusion, and after one year myocardial ischemia also improved, they concluded that "symptomatic relief precedes improvement of myocardial blood flow". In contrast to Mannheimer et al,94 noticing in their rapid atrial pacing study an instantaneous reduction in myocardial ischemia, followed by a relief in angina, during SCS, in the latter study with MIBI-SPECT nuclide, a reduction in myocardial ischemia was observed only after one year. The discrepancy in latency of effects may be related to two different mechanisms.

To further evaluate the influence of SCS on myocardial ischemia, Fricke and co-workers performed a Positron Emission Tomography (PET) study with 18F-FDG as tracer to detect changes in viability and $13 \mathrm{~N}$-ammonia as tracer for coronary flow reserve in patients with an implanted SCS for refractory angina. ${ }^{107}$ Irrespective of the improvement in clinical symptoms, the investigators failed to demonstrate significant alterations in coronary flow reserve. In contrast to their findings, two other observational studies, using ${ }^{13} \mathrm{NH}_{3}$ as tracer in patients with spinal cord stimulator implanted for refractory angina, reported blood flow directed from normally perfused regions to ischemic myocardial areas, in conjunction with an improvement in coronary flow reserve, resulting in a more homogenous perfused myocardium. ${ }^{108,109}$ This discrepancy in outcomes of the PET studies is thought to be related to differences in methodology, tracers, protocols and, tools. Furthermore, the redistribution in coronary blood flow from normally perfused to impaired perfused regions has also been observed following the administration of aminophyline, theofylline or bamiphylline and was coined "the Robin Hood phenomenon" (stealing from the "rich" non-ischemic areas and supplying the blood to the "poor" ischemic regions). ${ }^{110,} 111$ All these three drugs are affecting adenosine handling through their interaction with Xanthine metabolisme. Further, the adenosine re-uptake inhibitor dipyridamole blunts the effect of SCS 108 and the drinking of caffeine too has been reported to reduce the effects of neuromodulation through its effect on adenosine, via xanthine metabolism. ${ }^{112}$

Adenosine, administered in a coronary artery provokes angina through activation of adenosine A1 receptors. ${ }^{113,114}$ Adenosine plays a role in myocardial ischemia as well, which effect is thought to take place through activation of the A2 adenosine receptor, generating in 
its turn, under ischemic conditions, redistribution of local blood flow from sub-epicardial towards epicardial tissues. ${ }^{115}$ So, the moment the critical balance between myocardial oxygen supply and demand is deferred, by either improving supply, or through a reduction in demand, a cascade of chemical reactions take place. It is conceivable that electrical neuromodulation employs its effect through interference with local adenosine handling. ${ }^{116}$

In addition to the increased angina threshold, which was first addressed in the rapid atrial pacing study in patients with a SCS implanted for their angina, ${ }^{94}$ the observed antiischemic effects of SCS resluted in improvement of ischemic tolerance. Since the ischemic tolerance is considered as the result of collateral recruitment and preconditioning, the emphasis of the research was aimed at these two phenomena, in detail.

To unravel the mechanisms of action of electrical neuromodulation in cardiac performance, research was performed to the measuring of changes in coronary blood flow with Doppler flow catheters. In 1994, Chauhan et al showed an increase in coronary flow velocity in patients with refractory angina, during only 5 minutes' TENS.117 In contrast to their findings, observations in an anesthetized canine preparation of SCS, in which myocardial ischemia was created through a 4 minute ligation of a coronary artery, followed by application of radiolabeled microspheres to evaluate myocardial ischemia, suggest that blood flow in the microcirculation was not affected.118 Albeit that the occlusion was of very short duration and the canines did not show atherosclerotic coronary artery disease, this finding should not be surprising since it has been shown that the sympathetic nervous system does not seem to influence native coronary collateral vessels in canine myocardium. Other studies using Doppler flow wires confirm the initial results, ${ }^{119}$ most likely resulting from altered coronary collateral blood flow by a so-called reversed steal, following electrical neuromodulation. ${ }^{120}$ After the pilot phase, the recruitment of collaterals was demonstrated in a randomized control study during percutaneous coronary intervention and only 5 minutes of TENS.121 The altered coronary blood flows does not necessarily require an increase in blood flow velocity. ${ }^{122}$

The other branch to improve the ischemic tolerance of the heart, (pre)conditioning, has too been subjected to mechanistic studies. ${ }^{28}$ Initially, preconditioning was hypothesized to be induced through activation of protein kinase $C$ cascade, which phosphorylates the mitochondrial ATP-sensitive $\mathrm{K}^{+}$channels. This signalling pathway leads to preconditioning through a more gradual depletion of ATP-dependent energy storage mechanism. In the present concept of preconditioning, several signaling pathways play a role. Activation of signaling pathways are suggested to take place through release of substances like neurotransmitters and vasoactive compounds, such as adenosine and endorphins. Adenosine has vasodilatory effects and is involved in nociception. Therefore, it was postulated that adenosine may be the interface between neurohumoral and cardiovascular interactions. As a result of coffee intake and dipyridamole the metabolic handling adenosine appears to be affected, in the presence of electrical neuromodulation.108,112 Finally, electrical neuromodulation has been demonstrated both, to release beta-endorphins from the heart ${ }^{123}$ and to affect the alpha-receptor. ${ }^{124}$ These three prerequisites are all involved in the upregulation of $\mathrm{G}$ protein-coupled receptors which, in turn, activate ATP-sensitive $\mathrm{K}^{+}$ channels, through up-regulation of protein kinase C. In an experimental set up it was demonstrated that electrical neuromodulation mitigates transient ischemia in anesthetized rabbits. The animals were all subjected to 30 minutes of coronary arterial occlusion, followed 
by 3 hours of reperfusion, in the presence or absence of SCS at C8-T2. Pre-emptive electrical neuromodulation was able to reduce the ischemic zone, significantly, which effect was eliminated by a-receptor blockade. A polymerase chain reaction showed an increased phosphorylation of cardiac protein kinase C. This protein is known for its role in preconditioning. Furthermore, electrical neuromodulation did not seem to affect blood pressure or heart rate. It was concluded that pre-emptive electrical neurostimulation reduces the size of infarcts induced by transient coronary artery occlusion, which cardioprotective effect involves cardiac adrenergic neurons. ${ }^{124}$

Both limbs involved in ischemic tolerance, collateral recruitment and preconditioning may engage similar signaling pathways at time of myocardial reperfusion, i.e. protein kinase cascades.

In conclusion, based on enhanced ischemic tolerance it is conceivable that electrical neuromodulation employs its antiischemic cardioprotective effect by improving collateral flow, enhancing preconditioning and subsequently reducing myocardial oxygen demand.

\section{Final conclusions}

Electrical neuromodulation is an effective adjuct treatment for patients with refractory angina. Many studies showed that it is improving the quality of life of these patients who are severely disabled by their ischemic heart disease and also enhances the ischemic threshold. The antiischemic effect is thought to take place through activation of mechanisms which induce both preconditioning and recruitment of collaterals, without either increasing mortality rate and without concealing the angina warning signal, during an acute myocardial infarction. Therefore, neuromodulation is considered as a safe therapy for patients invalidated by their refractory angina. The underlying mechanisms of action are multi-factorial and take place at different levels in heart brain axis.

\section{Future developments}

Electrical neuromodulation for refractory angina is lacking a feed-back option, such as is the case in a pacing device, in which you can measure the threshold through assessing the capture. The determination of objective signs of an effect shall make the therapy more widely accepted. Notwithstanding the shortcomings, the use of various applications of electrical neuromodulation for a myriad of indications will develop further. It is conceivable that for transcutaneous nerve stimulation, instead of the pads that easily come off, a shirt with built-in pads will be developed. Further, a combination of electric devices such as a spinal cord stimulator and an ICD are likely. The spinal cord stimulator may stimulate prior to the ICD to reduce the sometimes freighting discharge of the ICD for the patient. Finally, newer cardiac indications such as in the treatment for tachy-arrhythmias, heart failure, cardiac syndrome $\mathrm{X}$ (microvascular angina) and acute coronary syndromes will be evaluated.

\section{References}

[1] Natelson BH. "Neurocardiology. An interdisciplinary area for the 80s". Arch Neurol (1985) 42:178-84.

[2] Basic and Clinical Neurocardiology. (Eds. Armour JA; Ardell JL). Oxford University Press, NY, USA (2004) 
[3] Heberden W. Some account of the breast. Med Trans (1772) 2:58-67

[4] Bolser DC, Chandler MJ, Garrison DW, Foreman RD. Effects of intracardiac bradykinin and capsaicin on spinal and spinoreticular neurons. Am J Physiol (1989) 257:H1543-50

[5] Albutaihi IA, Hautvast RW, DeJongste MJ, Ter Horst GJ, Staal MJ. Cardiac nociception in rats: neuronal pathways and the influence of dermal neurostimulation on conveyance to the central nervous system. J Mol Neurosci (2003) 43-52

[6] Albutaihi IA, DeJongste MJ, Ter Horst GJ. An integrated study of heart pain and behavior in freely moving rats (using fos as a marker for neuronal activation). Neurosignals (2004) 13:207-26

[7] Qin C, Farber JP, Miller KE, Foreman RD. Responses of thoracic spinal neurons to activation and desensitization of cardiac TRPV1-containing afferents in rats. Am J Physiol Regul Integr Comp Physiol (2006) 291:R1700-7

[8] Ter Horst GJ, Van den Brink A, Homminga SA, Hautvast RW, Rakhorst G, Mettenleiter TC, De Jongste MJ, Lie KI, Korf J. Transneuronal viral labelling of rat heart left ventricle controlling pathways. Neuroreport (1993) 4:1307-10

[9] Ter Horst GJ, Hautvast RW, De Jongste MJ, Korf J. Neuroanatomy of cardiac activityregulating circuitry: a transneuronal retrograde viral labelling study in the rat. Eur J Neurosci (1996) 8:2029-41

[10] DeJongste MJ, Terhorst GJ, Foreman RD. Basic research models for the study of underlying mechanisms of electrical neuromodulation and ischemic heart-brain interactions. Cleve Clin J Med (2009) 76 Suppl 2:S41-6

[11] Jessurun GAJ, Meeder JG, DeJongste MJL. Defining the problem of intractable angina. Pain Reviews, 1997;4:89-99

[12] Mannheimer C, Camici P, Chester MR, Collins A, DeJongste M, Eliasson T, Follath F, Hellemans I, Herlitz J, Luscher T, Pasic M, Thelle D. The problem of chronic refractory angina; report from the ESC Joint Study Group on the Treatment of Refractory Angina. Eur Heart J (2002) 23:355-70

[13] Ten Vaarwerk IAM. Jessurun GAJ, DeJongste MJL, Andersson C, Eliasson T, Mannheimer C, Staal MJ. On behalf of the working group neurocardiology. Baseline characteristics of patients with refractory AP treated with SCS. Heart (1999) 82:82-9

[14] Murray S, Carson KG, Ewings PD, Collins PD, James MA. Spinal Cord Stimulation significantly decreases the need for acute hospital admission for chest pain in patients with refractory angina pectoris. Heart (1999) 82:89-92

[15] Vulnink NCC, Overgaauw DM, Jessurun GAJ, TenVaarwerk IAM, Kropmans TJB, Van der Schans CP, Middel B, Staal MJ, DeJongste MJL.The effects of spinal cord stimulation on quality of life in patients with therapeutically refractory angina pectoris. Neuromodulaton (1999) 2:1:29-36

[16] Mukherjee D, Bhatt DL, Roe MT, Patel V, Ellis SG. Direct myocardial revascularization and angiogenesis--how many patients might be eligible? Am J Cardiol (1999) 84:598-600

[17] DeJongste MJ, Tio RA, Foreman RD Chronic therapeutically refractory angina pectoris. Heart (2004) 90:225-30

[18] Schoebel FC, Frazier OH, Jessurun GA, De Jongste MJ, Kadipasaoglu KA, Jax TW, Heintzen MP, Cooley DA, Strauer BE, Leschke M. Refractory angina pectoris in end-stage coronary artery disease: evolving therapeutic concepts. Am Heart J (1997) 134(4):587-602 
[19] Svorkdal N. Pro: anesthesiologists' role in treating refractory angina: spinal cord stimulators, thoracic epi- durals, therapeutic angiogenesis, and other emerging options. (2003) 17:536-45

[20] Gibbons RJ, Abrams J, Chatterjee K. ACC/AHA 2002 guideline update for management of patients with chronic stable angina--summary article: a report of the American College of Cardiology/American Heart Association Task Force on Practice Guidelines (Commit tee on the Management of Patients With Chronic Stable Angina). Circulation (2003) 107:149-58

[21] Nelson RR, Jorgenson CR, Wang Y. The rate pressure product as an index of myocardial oxygen consumption during exercise in patients with angina pectoris. Circulation (1987) 57:549-56

[22] Kersten JR, Pagel PS, Chilian WM, Warltier DC. Multifactorial basis for coronary collateralization: a complex adaptive response to ischemia. Cardiovasc Res (1999) 43:44-57

[23] A. Krogh A: The number and distribution of capillaries in muscles with calculations of the oxygen pressure head necessary for supplying tissue. J Physiol (1919) 52409-415 B. Krogh A: The supply of oxygen to the tissues and the regulation of the capillary circulation, J Physiol (1919) 52:457-474.

C. Krogh A: Anatomy and Physiology of Capillaries. New Haven Yale University Press. (1936)

[24] Billinger M, Fleisch M, Eberli FR, Garachemani A, Meier B, Seiler C. Is the development of myocardial tolerance to repeated ischemia in humans due to preconditioning or to collateral recruitment? J Am Coll Cardiol (1999) 33:1027-35

[25] Shattock MJ, Lawson CS, Hearse DJ, Downey JM. Electrophysiological characteristics of repetitive ischemic preconditioning in the pig heart. J Mol Cell Cardiol (1996) 28:1339-47

[26] Murry, CE; Jennings, RB, Reimer, KA. Preconditioning with ischemia: a delay of lethal cell injury in ischemic myocardium. Circulation (1986) 74:1124-36

[27] Garcia-Dorado D, Barba I, Inserte J. Twenty-five years of preconditioning: are we ready for ischaemia? From coronary occlusion to systems biology and back. Cardiovasc Res (2011) 91:378-81

[28] Hausenloy DJ, Yellon DM. The therapeutic potential of ischemic conditioning: an update. Nat Rev Cardiol (2011) 8:619-29

[29] Kellaway P. The William Osler Medical Essay. The part played by the electrical fish in the early history of bioelectricity and electrotherapy. Bull Hist Med (1946) 20:112

[30] Scheminzky, F: Recent Studies on Electronarcosis. Wien Klin Wschr (1936) 49:1190

[31] Melzack R, Wall PD. Pain mechanisms: a new theory. Science (1965) 150:971-9

[32] Rosen, S. D., Paulesu, E., Frith, C. D., Frackowiak, R. S. J., Davies, G. J. D., Jones, T. and Camici, P. G. (1994) Central nervous pathways mediating angina pectoris. Lancet, $344,147-150$.

[33] Hautvast RW, ter Horst GJ, DeJong B, DeJongste MJ, Blanksma PK, Paans AM, Korf J. Relative changes in regional cerebral blood flow during spinal cord stimulation in patients with refractory angina pectoris. Eur J of Neuroscience (1997) 9:1178-83

[34] Armour JA. Myocardial ischaemia and the cardiac nervous system. Cardiovasc Res, 1999; 41:41-54 (Review). 
[35] Beecher HK. Nonspecific forces surrounding disease and the treatment of disease. JAMA (1962) 179:137-40

[36] Chandler MJ, Brennan TJ, Garrison DW, Kim KS, Schwartz PJ, Foreman RD. A mechanism of cardiac pain suppression by spinal cord stimulation: implications for patients with angina pectoris. Eur Heart J (1993) 14:96-105

[37] Foreman RD, Linderoth B, Ardell JL, Barron KW, Chandler MJ, Hull SS Jr, TerHorst GJ, DeJongste MJ, Armour JA. Modulation of intrinsic cardiac neurons by spinal cord stimulat ion: implications for its therapeutic use in angina pectoris. Cardiovasc Res (2000) 47:367-75

[38] Gersbach PA, Hasdemir MG, Eeckhout E, von Segesser LK. Spinal cord stimulation treatment for angina pectoris: more than a placebo? Ann Thorac Surg (2001) 72:S1100-4

[39] Braunwald E, Epstein SE, Glick G, Wechsler AS, Braunwald NS. Relief of angina pectoris by electrical stimulation of the carotid-sinus nerves. New Engl J Med (1967) 277(24):1278-83

[40] Braunwald E. Personal reflections on efforts to reduce ischemic myocardial damage. Cardiovasc Res (2002) 56: 332-338

[41] Moore R, Groves D, Hammond C, Leach A, Chester MR.Temporary sympathectomy in the treatment of chronic refractory angina. J Pain Symptom Manage (2005) 30(2):183-91

[42] Mannheimer C, Carlsson CA, Ericson K, Vedin A, Wilhelmsson C.Transcutaneous electrical nerve stimulation in severe angina pectoris. Eur Heart J (1982) 3:297-302

[43] Mannheimer C, Carlsson CA, Emanuelsson H, vedin A, Waagstein F, Wilhelmsson C. The effects of trans- cutaneous electrical nerve stimulation in patients with severe angina pectoris. Circulation (1985) 71:308-16

[44] Strobos MA, Coenraads PJ, De Jongste MJ, Ubels FL.Dermatitis caused by radiofrequency electromagnetic radiation. Contact Dermatitis (2001) 44:309

[45] Llamas M, Santiago D, Navarro R, Sánchez-Pérez J, García-Diez A. Unusual allergic contact dermatitis produced by a transcutaneous electrical nerve stimulator. Contact Dermatitis (2010) 62:189-90

[46] Shealy CN, Taslitz N, Mortimer JT, Becker DP. Electrical inhibition of pain: experimental evaluation. Anesth Analg (1967) 46:299-305

[47] DeJongste MJ and Staal MJ. Electrical neuromodulation for chronic refractory angina pectoris. Res Adv in Cardiology (2001) 1:17-12

[48] Murphy DF and Giles KE. Dorsal column stimulation for pain relief from intractable angina pectoris. Pain (1987) 28:365-8

[49] Eddicks S, Maier-Hauff K, Schenk M, Müller A, Baumann G, Theres H. Thoracic spinal cord stimulation improves functional status and relieves symptoms in patients with refract ory angina pectoris: the first placebo-controlled randomised study. Heart (2007) 93:585-90

[50] Lanza GA, Grimaldi R, Greco S, Ghio S, Sarullo F, Zuin G, De Luca A, Allegri M, Di Pede F, Castagno D, Turco A, Sapio M, Pinato G, Cioni B, Trevi G, Crea F. Spinal cord stimulation for the treatment of refractory angina pectoris: a multicenter randomized single-blind study (the SCS-ITA trial). Pain (2011) 152:45-52

[51] Goroszeniuk T, Kothari S Subcutaneous Target Stimulation or Peripheral Subcutaneous Field Stimulation: That Is the Question. Neuromodulation (2011) 14:185-185 
[52] Buiten MS, DeJongste MJL, Beese U.Subcutaneous Electrical Nerve Stimulation: A Feasible and New Method for Treatment of Patients with Refractory Angina. Neuromodulation (2011) 14: 258-264

[53] Goroszeniuk T, Pang D, Al-Kaisy A, Sanderson K. Subcutaneous Target stimulationperipheral subcutaneous field stimulation in the treatment of refractory angina: preliminary case reports. Pain Practice (2011) 11:1-9

[54] Chester MR et al. A patient-centred guide to angina. www.agina.com

[55] González-Darder JM, Canela P, González-Martinez V. High cervical spinal cord stimulation for unstable angina pectoris. Stereotact Funct Neurosurg (1991) 56:20-27

[56] Murphy DF, Giles KE. Dorsal column stimulation for pain relief from intractable angina pectoris. Pain 1987; 28,365-368

[57] Sanderson JE, Brooksby P, Waterhouse D, Palmer RBG, Neuhauser K. Epidural spinal electrical stimulation for severe angina. A study of effects on symptoms, exercise tolerance and degree of ischemia. Eur Heart J (1992) 13:628-33

[58] De Vries J, De Jongste MJ, Spincemaille G, Staal MJ. Spinal cord Stimulation for ischemic heart disease and peripheral vascular disease. Adv Tech Stand Neurosurg (2007) 32:63-89

[59] Mannheimer C, Augustinsson LE, Carlsson CA et al. Epidural spinal electrical stimulation in severe angina pectoris. Br Heart J (1988) 59:56-61.

[60] Sanderson JE, Ibrahim B, Waterhouse D et al. Spinal electrical stimulation for intractable angina-long-term clinical outcome and safety. Eur Heart J (1994) 15:810-4

[61] Hautvast RW, DeJongste MJ, Staal MJ, Gilst van WH, Lie KI. Spinal cord stimulation in chronic intractable angina pectoris: a randomized, controlled efficacy study. Am Heart J (1998) 136:114-20

[62] Sanderson JE, Brooksby P, Waterhouse D, Palmer RB, Neubauer K. Epidural spinal electrical stimulation for severe angina: a study of its effects on symptoms, exercise tolerance and degree of ischaemia. Eur Heart J (1992) 13:628-33

[63] DeJongste MJL, Hautvast RWM, Hillege $\mathrm{H}$ et al. Efficacy of spinal cord stimulation as an adjuvant therapy for intractable angina pectoris: A prospective randomized clinical study. J Am Coll Cardiol (1994) 23:1592-7

[64] Bagger JP, Jensen BS, Johannsen G. Long-term outcome of spinal electrical stimulation in patients with refractory chest pain. Clin Cardiol (1998) 21:286-8

[65] Mannheimer C, Eliasson T, Augustinsson LE, Blomstrand C, Emanuelsson H, Larsson S, Norrsell H, Hjalmarsson A. Electrical stimulation versus coronary artery bypass surgery in severe angina pectoris: the ESBY study. Circulation (1998) 97:1157-63

[66] Jitta DJ, DeJongste MJL, Kliphuis CM, et al. Multimorbidity, the Predominant Predictor of Quality-of-Life, Following Successful Spinal Cord Stimulation for Angina Pectoris. Neuromodulation (2011) 14:13-18

[67] De Vries J, DeJongste MJ, Versteegen GJ.Personality:Predictor of neurostimulation outcom es in patients with chest pain and normal coronary arteries. Neuromodulation (2006) 9:123-127

[68] Dobre D, van Veldhuisen DJ, deJongste MJL, et al. The contribution of observational studies to the knowledge of drug effectiveness in heart failure $\mathrm{Br} J$ of Clin Pharmacol (2007) 64: 406-14 
[69] Börjesson M, Andrell P, Lundberg D, Mannheimer C. Spinal cord stimulation in severe angina pectoris--a systematic review based on the Swedish Council on Technology assessment in health care report on long-standing pain. Pain (2008) 140(3):501-8

[70] Taylor RS, De Vries J, Buchser E, DeJongste MJ. Spinal cord stimulation in the treatment of refractory angina: systematic review and meta-analysis of randomised controlled trials. BMC Cardiovasc Disord (2009) 25:9-13

[71] Gibbons RJ, Abrams J, Chatterjee K, et al. A Report of the American College of Cardiology/American Heart Association Task Force on Practice Guidelines (Committee on the Management of Patients With Chronic Stable Angina). ACC/AHA Guideline Update for the Management of Patients Stable Angina With Chronic -Summary Article. Circulation (2002) 107:149-58

[72] Vries J, Staal MJ, DeJongste MJL Is there a future for combinations of implantable devices in human bionics? Neuromodulation (2002) 5:131-132

[73] Iyer R, Gnanadurai TV, Forsey P. Management of cardiac pacemaker in a patient with spinal cord stimulator implant. Pain (1998) 74:333-5

[74] Enggaard TP, Andersen C, Scherer C. Spinal cord stimulation for refractory angina in pat ients implanted with cardioverter defibrillators: five case reports. Europace (2010) 121336-7

[75] Augustinsson LE, Eliasson T, Mannheimer C. Spinal cord stimulation in severe angina pectoris. Stereotact Funct Neurosurg (1995) 65:136-41

[76] Andersen C, Hole P, Oxhoj H. Does pain relief with spinal cord stimulation for angina conceal myocardial infarction ? Br Heart J (1994) 71:419-21

[77] Jessurun GAJ, TenVaarwerk IAM, DeJongste MJL et al. Sequalae of spinal cord stimulation for refractory angina pectoris. Reliabity and safety profile of long-term clinical application. Cor Artery Dis (1997) 8:33-7

[78] Di Pede F, Lanza GA, Zuin G, Alfieri O, Rapati M, Romanò M, Circo A, Cardano P, Bellocci F, Santini M, Maseri A; Immediate and long-term clinical outcome after spinal cord stimulation for refractory stable angina pectoris. Investigators of the Prospective Italian Registry of SCS for angina pecoris. Am J Cardiol (2003) 91:951-5

[79] Andréll P, Yu W, Gersbach P, Gillberg L, Pehrsson K, Hardy I, Stáhle A, Andersen C, Mannheimer C. Long-term effects of spinal cord stimulation on angina symptoms and quality of life in patients with refractory angina- results from the European Regaistry Link (EARL). Heart (2010);96:1132-6

[80] Simpson EL, Duenas A, Holmes MW, Papaioannou D, Chilcott J. Spinal cord stimulation for chronic pain of neuropathic or ischaemic origin: systematic review and economic evaluation. Health Technol Assess (2009) 13:iii, ix-x,1-154

[81] Dyer MT, Goldsmith KA, Khan SN, Sharples LD, Freeman C, Hardy I, Buxton MJ, Schofield PM. Clinical and cost-effectiveness analysis of an open label, singlecentre, randomised trial of spinal cord stimulation (SCS) versus percutaneous myocardial laser revascularisation (PMR) in patients with refractory angina pectoris: The SPiRiT trial. Trials (2008) 9:40

[82] Mulcahy D, Knight C, Stables R, Fox K. Lasers, burns, cuts, tingles and pumps: a consideration of alternative treatments for intractable angina. Br Heart J (1994) 71:406-8

[83] Cameron T. Safety and efficacy of spinal cord stimulation for the treatment of chronic pain: a 20-year literature. J Neurosurg (2004) 100:3;Suppl:S 254-267 (review) 
[84] de Vries J, Svilaas T, DeJongste MJL, et al. Impact of electrical neuro stimulation on persistent ST elevation after successful reperfusion by primary percutaneous coronary intervention. J of Electrocardiology (2007) 40:522-526

[85] De Vries J, DeJongste MJL, Zijlstra F, et al. Long-term effects of electrical neurostimulation in patients with unstable angina: Refractory to conventional therapies. Neuromodulation (2007) 10:345-48

[86] González-Darder JM, Canela P, González-Martinez V. High cervical spinal cord stimulation for unstable angina pectoris. Stereotact Funct Neurosurg (1991) 56:20-7.

[87] Greco S, Auriti A, Fiume D, Gazzeri G, Gentilucci G, Antonini L, Santini MSpinal cord stimulation for the treatment of refractory angina pectoris: a two-year follow-up. Pacing Clin Electrophysiol (1999) 22(1 Pt 1):26-32

[88] Diedrichs H, Zobel C, Theissen P, Weber M, Koulousakis A, Schicha H, Schwinger RH. Symptomatic relief precedes improvement of myocardial blood flow in patients under spinal cord stimulation. Curr Control Trials Cardiovasc Med (2005) 19;6:7

[89] DeJongste MJL, Haaksma J, Hautvast RW Hillege HL, Meyler PW, Staal MJ, Sanderson JE, Lie KI. Effects of spinal cord stimulation on daily life myocardial ischemia in patients with severe coronary artery disease. A prospective ambulatory ECG study. Br Heart J (1994) 71:413-8

[90] Murray S, Collins PD, James MA. An investigation into the 'carry over' effect of neurostimulation in the treatment of angina pectoris. Int J Clin Pract (2004) 58(7):669-74

[91] Shealy CN et al. Electrical inhibition of pain: experimental evaluation. Anesth Analg, 1967;46:299-305

[92] Armour JA, Linderoth B, Arora RC, DeJongste MJ, Ardell JL, Kingma JG Jr, Hill M, Foreman RD. Long-term modulation of the intrinsic cardiac nervous system by spinal cord neurons in normal and ischaemic hearts. Auton Neurosci (2002) 10;95:71-9

[93] Jessurun GA, DeJongste MJ, Hautvast RW, Tio RA, Brouwer J, van Lelieveld S, Crijns HJ.Clinical follow-up after cessation of chronic electrical neuromodulation in patients with severe coronary artery disease: a prospective randomized controlled study on putative involvement of sympathetic activity. Pacing Clin Electrophysiol (1999) 22:1432-9

[94] Mannheimer C, Eliasson T, Andersson B et al. Effects of spinal cord stimulation in angina pectoris induced by pacing and possible mechanisms of action. Br Med J (1993) 307:477-80

[95] Lindgrin I. Angina pectoris; a clinical study with special reference to neurosurgical treatment. Acta Med Scand Suppl (1950) 243:1-203.

[96] Meglio M, Cioni B, Rossi GF, Sandric S, Santarelli P. Spinal cord stimulation affects the central mechanisms of regulation of heart rate. J Appl Neurophysiol (1986) 49(3):139-46

[97] Balcon R, Jewitt DE, Davies JP, Oram S A controlled trial of propranolol in acute myocardial infarction. Lancet (1966) 2(7470):918-20

[98] Hautvast RW, Brouwer J, DeJongste MJ, Lie KI. Effect of spinal cord stimulation on heart rate variability and myocardial ischemia in patients with chronic intractable angina pectoris--a prospective ambulatory electrocardiographic study. Clin Cardiol (1998) 21:33-8 
[99] Norrsell H, Eliasson T, Mannheimer C, Augustinsson LE, Bergh CH, Andersson B, Waag stein F, Friberg P. Effects of pacing-induced myocardial stress and spinal cord stimulation on whole body and cardiac norepinephrine spillover. Eur Heart J (1997);18:1890-6

[100] Fricke E, Eckert S, Dongas A, Fricke H, Preuss R, Lindner O, Horstkotte D, Burchert W. Myocardial sympathetic innervation in patients with symptomatic coronary artery disease: follow-up after 1 year with neurostimulation. J Nucl Med (2008) 49(9):1458-64

[101] Spinelli A, Lanza GA, Calcagni ML, Sestito A, Sgueglia GA, Di Monaco A, Bruno I, Lamendola P, Barone L, Giordano A, Crea F. Effect of spinal cord stimulation on cardiac adr energic nerve function in patients with cardiac syndrome X. J Nucl Cardiol (2008)15:804-10

[102] Kudej RK, Shen YT, Peppas AP, Huang CH, Chen W, Yan L, et al Obligatory role of cardiac nerves and alpha1-adrenergic receptors for the second window of ischemic preconditioning in conscious pigs. Circ Res 2006;99:1270-1276

[103] Olgin JE, Takahashi T, Wilson E, Vereckei A, Steinberg H, Zipes DP. Effects of thoracic spinal cord stimulation on cardiac autonomic regulation of the sinus and atrioventricular nodes. J Cardiovasc Electrophysiol (2002) 13:475-81

[104] Zamotrinsky AV, Kondratiev B, de Jong JW. Vagal neurostimulation in patients with coronary artery disease. Auton Neurosci ( 2001) 88(1-2):109-16

[105] Marber M, Walker D, Yellon D. Spinal cord stimulation or ischemic preconditioning? Br Med J (1993) 307:737

[106] Diedrichs H, Zobel C, Theissen P, Weber M, Koulousakis A, Schicha H, Schwinger RH. Symptomatic relief precedes improvement of myocardial blood flow in patients under spinal cord stimulation. Curr Control Trials Cardiovasc Med (2005) 6:7

[107] Fricke E, Eckert S, Dongas A, Fricke H, Preuss R, Lindner O, Horstkotte D, Burchert W. Myocardial perfusion after one year of spinal cord stimulation in patients with refractory angina. Nuklearmedizin (2009) 48:104-9

[108] Hautvast RW, Blanksma PK, DeJongste MJ, Pruim J, van der Wall EE, Vaalburg W, Lie KI. Effect of spinal cord stimulation on myocardial blood flow assessed by positron emission tomography in patients with refractory angina pectoris. Am J Cardiol (1996) 1;77:462-7

[109] Mobilia G, Zuin G, Zanco P, Di Pede F, Pinato G, Neri G, Cargnel S, Raviele A, Ferlin $G$, Buchberger R. Effects of spinal cord stimulation on regional myocardial blood flow in patients with refractory angina. A positron emission tomography study. $G$ Ital Cardiol (1998) 28:1113-9.

[110] Crea F, Pupita G, Galassi AR, el Tamimi H, Kaski JC, Davies GJ, Maseri A. Effect of theophylline on exercise-induced myocardial ischaemia. Lancet (1989) 1(8640):683-6

[111] Gaspardone A, Crea F, Iamele M, Tomai F, Versaci F, Pellegrino A, Chiariello L, Gioffré PA. Bamiphylline improves exercise-induced myocardial ischemia through a novel mechanism of action. Circulation (1993) 88:502-8

[112] Marchand S, Li J, Charest J. Effects of caffeine on algesia from transcutaneous electrical nerve stimulation. New Eng J Med (1995) 333:325-6

[113] Lagerqvist B, Sylvén C, Beermann B, Helmius G, Waldenström A. Intracoronary adenosine causes angina pectoris like pain--an inquiry into the nature of visceral pain. Cardiovasc Res (1990) 24:609-13 
[114] Gaspardone A, Crea F, Tomai F, Versaci F, Iamele M, Gioffrè G, Chiariello L, Gioffrè PA. Muscular and cardiac adenosine-induced pain is mediated by A1 receptors.. J Am Coll Cardiol (1995) 25:251-7

[115] Berwick ZC, Payne GA, Lynch B, Dick GM, Sturek M, Tune JD. Contribution of adenosine $\mathrm{A}(2 \mathrm{~A})$ and $\mathrm{A}(2 \mathrm{~B})$ receptors to ischemic coronary dilation: role of $\mathrm{K}(\mathrm{V})$ and K(ATP) channels. Microcirculation (2010) 17:600-7

[116] Szentmiklósi AJ, Cseppento A, Harmati G, Nánási PP. Novel trends in the treatment of cardiovascular disorders: site- and event- selective adenosinergic drugs. Curr Med Chem (2011) 18:1164-87

[117] Chauhan A, Mullins PA, Thuraisingham SI, Taylor G, Petch MC, Schofield PM.. Effect of transcutaneous electrical nerve stimulation on coronary blood flow. Circulation (1994) 89:694-70

[118] Kingma JG Jr, Linderoth B, Ardell JL, Armour JA, DeJongste MJ, Foreman RD. Neuromodulation therapy does not influence blood flow distribution or leftventricular dynamics during acute myocardial ischemia. Auton Neurosci (2001) 91:47-54

[119] Jessurun GA, Tio RT, DeJongste MJ et al. Coronary blood flow dynamics during transcutaneous electrical stimulation for stable angina pectoris associated with severe narrowing of one major coronary artery. Am J Cardiol (1998) 82:921-6

[120] De Vries J, Anthonio RL, DeJongste MJL, Jessurun GA, Tio RA, Zijlstra F. The effect of electrical neurostimulation on collateral perfusion. Netherlands Heart J ( 2006) 14:209-14

[121] De Vries J, Anthonio RL, DeJongste MJ, Jessurun GA, Tan ES, de Smet BJ, van den Heuvel AF, Staal MJ, Zijlstra F. The effect of electrical neurostimulation on collateral perfusion during acute coronary occlusion. BMC Cardiovasc Disord (2007) 7:18

[122] Norrsell H, Eliasson T, Albertsson P, Augustinsson LE, Emanuelsson H, Eriksson P, Mannheimer C. Effects of spinal cord stimulation on coronary blood flow velocity. Coron Artery Dis (1998) 9:273-8

[123] Eliasson T, Mannheimer C, Waagstein F, Andersson B, Bergh CH, Augustinsson LE, Hedner T, Larson G. Myocardial turnover of endogenous opioids and calcitoningene-related peptide in the human heart and the effects of spinal cord stimulation on pacing-induced angina pectoris. Cardiology (1998) 89:170-7

[124] Southerland EM, Milhorn DM, Foreman RD, Linderoth B, DeJongste MJ, Armour JA, Subramanian V, Singh M, Singh K, Ardell JL. Preemptive, but not reactive, spinal cord stimulation mitigates transient ischemia-induced myocardial infarction via cardiac adrenergic neurons. Am J Physiol Heart Circ Physiol (2007) 292:H311-7 


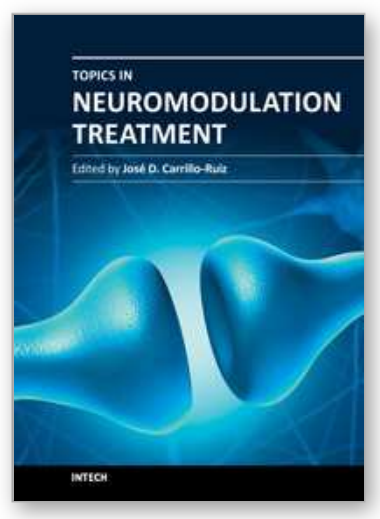

\section{Topics in Neuromodulation Treatment}

Edited by Dr. José Carrillo-Ruiz

ISBN 978-953-51-0395-0

Hard cover, 190 pages

Publisher InTech

Published online 23, March, 2012

Published in print edition March, 2012

"Topics in Neuromodulation Treatment" is a book that invites to the reader to make an update in this important and well-defined area involved in the Neuroscience world. The book pays attention in some aspects of the electrical therapy and also in the drug delivery management of several neurological illnesses including the classic ones like epilepsy, Parkinson's disease, pain, and other indications more recently incorporated to this important tool like bladder incontinency, heart ischemia and stroke. The manuscript is dedicated not only to the expert, but also to the scientist that begins in this amazing field. The authors are physicians of different specialties and they guarantee the clinical expertise to provide to the reader the best guide to treat the patient.

\section{How to reference}

In order to correctly reference this scholarly work, feel free to copy and paste the following:

Mike J.L. DeJongste (2012). Electrical Neuromodulation and the Heart with Special Emphasis on Myocardial Ischemia, Topics in Neuromodulation Treatment, Dr. José Carrillo-Ruiz (Ed.), ISBN: 978-953-51-0395-0, InTech, Available from: http://www.intechopen.com/books/topics-in-neuromodulation-treatment/electricalneuromodulation-and-the-heart-with-special-focus-on-myocardial-ischemia

\section{INTECH}

open science | open minds

\section{InTech Europe}

University Campus STeP Ri Slavka Krautzeka 83/A 51000 Rijeka, Croatia Phone: +385 (51) 770447

Fax: +385 (51) 686166 www.intechopen.com

\section{InTech China}

Unit 405, Office Block, Hotel Equatorial Shanghai No.65, Yan An Road (West), Shanghai, 200040, China 中国上海市延安西路65号上海国际贵都大饭店办公楼 405 单元 Phone: +86-21-62489820

Fax: $+86-21-62489821$ 
(C) 2012 The Author(s). Licensee IntechOpen. This is an open access article distributed under the terms of the Creative Commons Attribution 3.0 License, which permits unrestricted use, distribution, and reproduction in any medium, provided the original work is properly cited. 